\title{
DIVINE COMMANDS ARE UNNECESSARY FOR MORAL OBLIGATION
}

\author{
Erik J. Wielenberg
}

$\prod$

IVINE COMMAND THEORY is experiencing something of a renaissance, inspired in large part by Robert Adams's 1999 masterpiece Finite and Infinite Goods. The basic ethical framework presented in that book has significantly influenced later work on divine command theory (DCT) by William Wainwright, David Baggett and Jerry Walls, C. Stephen Evans, and John Hare. ${ }^{1}$ DCT's central claims are that (i) $S$ is morally obligated to do $A$ just in case God commands $S$ to do $A$ and (ii) all moral obligations are somehow grounded in or generated by divine commands. DCT-ists spell out this grounding relation differently. ${ }^{2}$ Adams, for example, suggests that human moral obligations are constituted by the commands of a good and loving God. ${ }^{3}$

One prominent challenge to DСт alleges that divine commands are not always sufficient for moral obligation. For instance, it has been claimed that even if God were to command the torture of innocent children, torturing innocent children would not be morally obligatory. ${ }^{4}$ Here I develop a challenge to DCT that has received much less attention: I argue that divine commands are not always necessary for actions to be morally obligatory. ${ }^{5}$ One way of developing such an

1 Wainwright, Reason and Morality; Baggett and Walls, Good God; Evans, God and Moral Obligation; and Hare, God's Command.

2 See Murphy, "Theological Voluntarism."

3 Adams, Finite and Infinite Goods, 250, 281.

4 See Morriston, "What If God Commanded Something Terrible?"; and Pruss, "Another Step in Divine Command Dialectics."

5 Arguments for a similar conclusion have been advanced by Wainwright, Reason and Morality, 80-83; Wielenberg, Value and Virtue in a Godless Universe, 53-67; Manis, Virtue, Divine Commands and the Debt of Creation, 106 and 117-26; Wolterstorff, Justice, 272; and Murphy, God and Moral Law, 116-32. The argument here differs from those arguments in that I seek to leverage the typical commitments of contemporary DСТ-ists in order to undermine their position that divine commands are necessary for moral obligations. The argument of this paper is also distinct from the "prior obligations" objection, which focuses on the obligation to obey God's commands (Evans, God and Moral Obligation, 98-101). The argument here is most similar to the argument of Manis; the main difference is that Manis's argument is tied 
argument would be to defend a moral theory that is an alternative to DCT-utilitarianism, for example - and show that the alternative theory implies that there are some moral obligations not grounded in divine commands. We might call that an external critique of DCT. I will instead develop what could be called an internal critique of ВСТ, making the case that the ВСТ-ist's own commitments put pressure on her to concede the existence of some moral obligations that in no way depend on divine commands. Focusing on Robert Adams's theistic framework for ethics, I will argue that Adams's views about good, evil, reasons, and the nature of moral obligation suggest that there can be moral obligations that exist independently of any divine commands. My argument proceeds through the development of an example in which there is a moral obligation that is not even partially grounded in a divine command. I focus primarily on Adams's view because, as I noted above, many contemporary DCT-ists work in a broadly Adamsian framework, so the argument I advance here poses a challenge for many contemporary versions of DCT.

\section{THE MAIN ARGUMENT}

Adams develops what he calls a "theistic framework for ethics," of which DCT is just one part. ${ }^{6} \mathrm{He}$ offers distinct accounts of three central ethical phenomena: (i) the Good, which is a transcendent paradigm of goodness, (ii) the goodness of finite things, and (iii) moral obligation. Adams proposes that the Good is God, finite goodness is resemblance to the necessarily existing divine nature, and moral obligation is being commanded by God. Note that these are claims not about the meaning of the words "good" or "obligatory" but rather about the nature of goodness and moral obligation. Adams claims that the meaning of a given term does not always reveal the full nature of the thing to which the term refers. ${ }^{7}$ An implication of Adams's view is that there are many facts about good and evil that do not depend on any divine commands. Relatedly, Adams's view implies that there are some reasons that exist independently of divine commands-reasons not in the psychological sense, as actual psychological motives, but rather in the objective or justifying or normative or third-person sense, as features that count in favor of a course of action whether they actually motivate anyone or not. For example, Adams asserts that the goodness of the consequences of a given action

specifically to the ideas of Kierkegaard whereas the argument here focuses primarily on the view of Adams. My argument can perhaps be understood as a fleshing out of a challenge for DCT that Murphy gestures toward in section 3.3 of God and Moral Law.

6 Adams, Finite and Infinite Goods, 4.

7 Adams, Finite and Infinite Goods, 15-16. 
provides a reason to perform that action and also that the fact that an act is "good, either intrinsically or by serving a pattern of life that is very good" provides a reason to perform the act. ${ }^{8}$ Since good and evil can exist independently of God's commands, there are reasons - indeed, moral reasons — for and against various courses of action independently of any divine command. ${ }^{9}$

Suppose, then, that I make a solemn promise to my wife to end my practice of staying out late drinking - a practice that, let us suppose, has significantly damaged our relationship, a relationship that is valuable and that I in fact value deeply. Keeping this promise would have good consequences and would serve a pattern of life that is very good, and so, by Adams's lights, there are good reasons for me to keep the promise. Adams suggests that

valuing one's social bonds gives one, under certain conditions, a reason to do what is required of one's associates or one's community.... I value the relationship which I see myself as actually having, and my complying is an expression of my valuing and respecting the relationship. ${ }^{10}$

Adams here speaks of a case in which one party has made a demand of another, but it is plausible that something similar holds in the case of a promise like the one described above. I value the relationship with my wife, and my keeping my promise is an expression of my valuing and respecting the relationship; that is a (moral) reason to keep the promise.

Accordingly, independently of any divine commands, there are strong moral reasons for me to keep my promise to refrain from staying out late drinking. We can bring further reasons to keep the promise into the picture by drawing on Adams's views about evil. Adams suggests that evil can be understood as being related to the divine nature in a way other than resemblance or similarity. One important kind of badness is constituted by attacking or opposing something good. And one particularly nasty form of attacking something good is what Adams calls "morally horrible." Some acts in this category are "rape, murder, and maiming, torturing, or brainwashing a human being." 11 According to Adams, what makes these sorts of acts particularly bad is that they are all violations of human persons, who are sacred images of God. Such violations are acts that attack persons seriously and directly; their foreseeable effects are so damaging to

8 Adams, Finite and Infinite Goods, 241, 255.

9 That these reasons are properly classified as moral reasons on Adams's view is suggested by the fact that on his view, these are the sorts of reasons for action generated by moral obligations. 
their victims that fully intending them constitutes hostility toward their victims. Adams says that without any divine commands, murder and torture would not be morally wrong "but they would still be bad, and specifically horrible." ${ }^{12}$

Suppose now that I find myself at the bar early one evening. I have had a couple of drinks but I have not yet stayed out late drinking, so I have not broken my promise. Suppose further that things are turning ugly; the group I am with is turning toward drinking hard liquor, and I can foresee that if I stay at the bar and participate in the drinking of hard liquor, there is a good chance that I will be a participant in a murder later in the evening. Now I have an additional compelling moral reason to keep my promise to my wife: if I do not keep the promise on this occasion, there is a good chance that I will participate in a morally horrible act. In this situation, there are several powerful moral reasons in favor of me keeping my promise and very few (and no powerful) reasons in favor of me breaking my promise. Overall, then, it seems that I have moral reasons for keeping my promise that are both powerful and decisive. ${ }^{13}$

I suggest that in the example I have described, I am morally obligated to keep my promise and that this obligation exists independently of any divine commands. As I just noted, I have powerful and decisive moral reasons to keep the promise. ${ }^{14}$ Keeping the promise has many of the features that Adams and Evans (another prominent DCT-ist) identify as defining features of moral obligations: It is something I should take seriously and care about. ${ }^{15}$ If I give the various reasons described above the appropriate weight, then I will be strongly motivated to keep the promise. ${ }^{16}$ If I break the promise and am responsible for doing so, then I am guilty and blameworthy. ${ }^{17}$ There is someone (my wife) who has the right to expect me to keep my promise and who may rightly be disappointed in

Adams, Finite and Infinite Goods, 105, 107-8.

See Parfit, On What Matters, 33.

Adams offers an argument against the principle that the morally obligatory is "what we have most reason (from a moral point of view) to do," so I should note that my argument does not depend on any such principle (Finite and Infinite Goods, 238). My argument is rather an argument from counterexample; I build a case that seems to have the various marks of moral obligation identified by Adams independently of any divine command. Adams describes a case in which "the preponderance of moral reasons favors your not walking on the lawn, but also favors not worrying about it very much and not feeling guilty if you do it," suggesting that in such a case there is no moral obligation not to walk on the lawn (Finite and Infinite Goods, 238). But in my example, there are strong reasons for me to worry about keeping my promise and to feel guilty if I break it.

5 Adams, Finite and Infinite Goods, 235; Evans, God and Moral Obligation, 31.

Adams, Finite and Infinite Goods, 235; Evans, God and Moral Obligation, 31.

Adams, Finite and Infinite Goods, 235. 
me and blame me if I fail to keep my promise. ${ }^{18}$ Adams writes approvingly of Mill's claim that "we do not call anything wrong, unless we mean to imply that a person ought to be punished in some way or other for doing it; if not by law, by the opinion of his fellow creatures; if not by opinion, by the reproaches of his own conscience." ${ }^{19}$ Not only do I have powerful reasons not to remain at the bar, but there is also reason for me to feel guilty and hence be punished by my own conscience if I remain at the bar, and there is reason for others-particularly my wife-to punish me by their opinions of me.

The DСт-ist must deny that all of this is sufficient to give me a genuine moral obligation to keep my promise. But why? What is it that a divine command adds to the situation that is supposed to make the difference between my not being morally obligated to keep my promise and my being so obligated? At least part of the answer seems to be that a divine command brings additional powerful reasons into the situation. So, suppose that God commands me to keep my promise. I now have further reasons to keep the promise, reasons grounded in the goodness of my relationship with God and in the goodness of God himself. ${ }^{20}$ Evans acknowledges that there may be "strong, even overriding reasons" to perform a given action independently of any divine command. He suggests that "God's command introduces a new character to the situation that the act alone without the command would not possess" and that "we acquire powerful new reasons for performing (or not performing) various acts when God issues commands."11 That seems plausible, but it is not plausible to suppose that piling on more reasons somehow makes the difference between my not having and my having a moral obligation to keep the promise. Even without the divine command, there are powerful and decisive moral reasons for me to keep the promise, and the command does not add to the situation any of the defining marks of moral obligation identified by Adams or Evans.

One feature that is missing from the promise-keeping example is a demand. In my example, I have made a promise, but no one has demanded anything of anyone else. Adams declares that "having an obligation to do something consists in being required ... by another person or group of persons, to do it." ${ }^{22}$ But Adams seems not to provide any support for the claim that it is essential to the nature of moral obligation that it include a literal demand from someone. Of

Evans, God and Moral Obligation, 27.

Mill, Utilitarianism, 48-49. See Adams, Finite and Infinite Goods, 233-34.

Adams, Finite and Infinite Goods, 252-53.

Evans, God and Moral Obligation, 36, 69.

Adams, Finite and Infinite Goods, 242. For a helpful critical discussion of this alleged "social character" of moral obligation, see Murphy, God and Moral Law, 124-32. 
course, one may stipulate that they will use "moral obligation" in a particular way, and so it is open to the ВСт-ist to declare that when they use "moral obligation," they mean something like "a moral requirement constituted by a demand from another person." But then the debate between the ВСт-ist and her opponent becomes a purely semantic one upon which nothing of substance hangs. Adams's view of good, evil, and reasons suggests that, independently of any divine commands, there can be actions that a person has powerful and decisive moral reasons to perform, that should be taken seriously, that one can be strongly motivated to perform, that one is guilty and blameworthy for (responsibly) failing to perform, and that one deserves punishment for (responsibly) failing to perform. There is no good reason to insist that such acts are genuinely morally obligatory only if someone demands that they be performed. ${ }^{23}$

Adams suggests that moral obligation "grounds reasons for action." ${ }^{24}$ These remarks suggest the view that what constitutes $S$ 's moral obligation to do $A$ is the facts that generate moral reasons for $S$ to do $A$ (and perhaps to feel guilty if $S$ neglects to do $A$, and for others to blame $S$ for responsibly failing to do $A$ ). Adams says that what constitutes $S$ 's moral obligation to do $A$ is the command of a good and loving God to $S$ to do $A$. However, strictly speaking, it seems that on Adams's view moral obligations are also partially constituted by certain other facts, such as $S$ having a valuable relationship with God, God having done various things for $S$, and $A$ itself being good. ${ }^{25}$ Accordingly, in the promise-keeping example described above, what constitutes my moral obligation to refrain from staying out late drinking is my promise to my wife-or more precisely, the promise together with our relationship and various other relevant features of the situation. Other moral obligations in other circumstances are constituted by different reason-giving features of the situation. While DCT offers what we might call a monist account of what constitutes moral obligations (moral obligations are always constituted by divine commands), a plausible alternative is a pluralist account where moral obligations are constituted by different sorts of facts in different situations - an account along broadly Rossian lines. ${ }^{26}$

Perhaps one thought behind DCT is that obligations are moral demands; on DCT, God is morality, and morality literally demands things of us! But this line of thought seems to be driven by an excessively literal understanding of "moral demands."

25 Adams, Finite and Infinite Goods, 252-53. 


\section{CONCLUSION}

I have argued that ВСT goes wrong in its central claim that all moral obligations are somehow grounded in divine commands. This is not to deny that if God exists and issues commands, his commands generate moral obligations. Divine commands may, for instance, turn acts that would otherwise be merely morally permissible - such as loving one's neighbors with all of one's heart-into acts that are morally obligatory. ${ }^{27}$ The main lesson of the present discussion is that it is going too far to claim that only a divine command can give rise to a moral obligation; the correct view is that divine commands are one among many possible sources of moral obligation. ${ }^{28}$

DePauw University ewielenberg@depauw.edu

\section{REFERENCES}

Adams, Robert. Finite and Infinite Goods: A Theistic Framework for Ethics. Oxford: Oxford University Press, 1999.

Baggett, David, and Jerry L. Walls. Good God: The Theistic Foundations of Morality. Oxford: Oxford University Press, 2011.

Evans, C. Stephen. God and Moral Obligation. Oxford: Oxford University Press, 2013.

Hare, John. God's Command. Oxford: Oxford University Press, 2015.

Manis, R. Zachary. Virtue, Divine Commands and the Debt of Creation: Towards a Kierkegaardian Christian Ethic. PhD diss., Baylor University, 2006.

Mill, John Stuart. Utilitarianism. Edited by George Sher. 2nd ed. Indianapolis: Hackett, 2001.

Morriston, Wes. "What If God Commanded Something Terrible? A Worry for Divine-Command Meta-Ethics." Religious Studies 45, no. 3 (Summer 2009): 249-67.

Murphy, Mark. God and Moral Law: On the Theistic Explanation of Morality. Oxford: Oxford University Press, 2011.

. "Theological Voluntarism." Stanford Encyclopedia of Philosophy (Summer 2019). https://plato.stanford.edu/archives/sum2019/entries/voluntarism -theological/.

27 Quinn, "Divine Command Theory."

28 I am grateful to Wes Morriston for helpful discussion of the argument of this paper. 
Parfit, Derek. On What Matters. Vol. 1. Oxford: Oxford University Press, 2011.

Pruss, Alexander. "Another Step in Divine Command Dialectics." Faith and Philosophy 26, no. 4 (October 2009): 432-39.

Quinn, Philip. "Divine Command Theory." In The Blackwell Guide to Ethical Theory, 2nd ed., edited by Hugh LaFollette, 81-102. Oxford: Blackwell, 2013.

Ross, David. The Right and the Good. Edited by Philip Stratton-Lake. 2nd ed. Oxford: Oxford University Press, 2003.

Wainwright, William. Reason and Morality. Burlington, vT: Ashgate, 2005.

Wielenberg, Erik. Value and Virtue in a Godless Universe. Cambridge: Cambridge University Press, 2005.

Wolterstorff, Nicholas. Justice: Rights and Wrongs. Princeton: Princeton University Press, 2008. 